\title{
Veterem atque antiquam rem novam ad vos proferam: A New Drama, a Surprised Audience, and a 'Live Aetiology'
}

Performing the Origin of the Amphitruo

\author{
Andrea de March
}

In this chapter the term 'aetiology' will not be employed according to its usual meaning, namely a mythical narrative that explains the origins of some cultic ritual or institution, ${ }^{1}$ as in Harder's and Klooster's investigations. Rather, consistently with the genre of the text that will be analysed in what follows (i.e. comedy), a possible case of performed, or 'live aetiology' is taken into account. As it will be shown, the peculiarity of a staged aetiology consists of its seemingly improvised character, which aims to clarify some aspects of the drama itself that are supposed to disappoint the spectators right after being announced in the prologue. Of course, clarification and the ensuing conciliation with the disappointed audience are accomplished by means of a genetic account of the seeming anomalies.

This is what allegedly happens at the start of Plautus' Amphitruo, where the announced presence of gods, which is a paradigmatically tragic feature, and the imagined confusion this causes amongst an audience expecting a comedy, becomes a fictive pretext for an apparently instantaneous rewrite of the play (seemingly, a tragedy) into a comedy, and thus for an instantaneous

* This chapter has been written with the support of the Anchoring Innovation research project. Anchoring Innovation is the Gravitation Grant research agenda of the Dutch National Research School in Classical Studies, OIKOS. It is financially supported by the Dutch ministry of Education, Culture and Science (NWO project number 024.003.012). For more information about the research programme and its results, see the website www.anchoring innovation.nl.

1 Nevertheless, in the case study I am going to present, the general function of aetiology

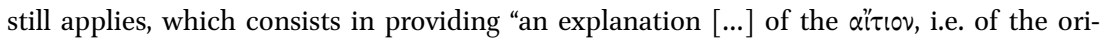
gin, of some phenomenon affecting the present-day situation of the author and his public" (Fantuzzi 2006). 
metamorphosis of its genre. It is the god Mercury (the prologue-speaker and one of the gods starring in the play) that, speaking on Plautus' behalf as his meta-poetic mouthpiece, simultaneously triggers and dissipates the spectators' disappointment. However extravagant, Mercury's puzzling announcement and simultaneous offer to instantly transform the play's genre will prove to be in fact a crucial rhetorical device aiming to promote the eccentric nature of the Amphitruo, a self-proclaimed tragicomedy (tragicomoedia, 1. 63, see below). Therefore, Mercury's generic metamorphosis promotes the acceptance of a new and seemingly hybrid kind of drama by inventing on the spot the reason ${ }^{2}$ of the presence of tragic features in what is supposed to be a comedy. The spectators themselves, with their surprise at the announcement of a tragedy, are made the first direct cause (i.e. the $\alpha$ il $\tau$ ov) of the drama's generic heterogeneity.

It will be shown also that Mercury's 'live aetiology', which develops an explanatory and persuasive discourse, ${ }^{3}$ shares the anchoring function that already used to recur in ancient aetiological discourses. Mercury's metamorphosis will not completely change the plays' generic status, but will make the tragic elements of the Amphitruo acceptable for the audience by anchoring them in a frame that helps the spectators find the expected and longed for comic side of the play (i.e. the presence of the comic servus callidus together with the tragic gods).

2

\section{Staged and Scholarly Aetiologies: Plautus and Plautinists in Search of an Origin}

Therefore, Mercury's remarkable concern with the development of an aetiological account of the play's origin from a veterem atque antiquam rem (l. 118, see below), namely from an 'old and ancient thing', betrays his need for legitimacy. As will soon become clear, Mercury fears that some spectators might reject his announcement of a hybrid play as not conforming to the established literary conventions. Therefore, by emphatically stressing the antiquity of the alleged source, he seems to counterbalance the 'surprise effect' of the

2 Pace Gunderson 2015, 183: "[T] he prologue of the Amphitruo [...] gestures more to the symptoms than to the cause."

3 Therefore aetiology can be equated with other ancient "discursive practices" such as mythology, genealogy, and etymology whose function is to provide a "tool for thinking" (Denkform) that helps the understanding of current situations by putting "emphasis on causality, motivation, and explanation" (see Sluiter 2015, 899-903). 
announced newness of the current drama. ${ }^{4}$ Moreover, by ending the aetiology of the Amphitruo with the mention of an anonymous model (res) whose antiquity affectedly attests to the play's inclusion of a traditional (Greek) dramatic storyline and repertoire, Mercury exploits a reassuring device that anchors such a drama as Plautus' Amphitruo in the common ground of the recipients, to whom it would otherwise appear unfamiliar. ${ }^{5}$

At this point, before starting my reading of the prologue to the Amphitruo, a very short methodological premise is necessary, given the vast and complex articulation of Plautine studies. ${ }^{6}$ The recurrence in Plautus' palliatae of a dramatic repertoire that manifestly recalls that of Hellenistic New Comedy (Nea) is traditionally interpreted by scholars as the result of the poet's participation in the "translation project"7 of Greek literary works that allegedly marked the beginnings of Latin literature. This view, partly based on Plautus' own (ironic) definition of his comedies as 'barbarian translations' of some specified Greek models, ${ }^{8}$ has been so dominant that several generations of Plautinists concentrated their efforts on trying to assess the poet's degree of originality and faithfulness towards his models, often with the ultimate aim of reconstructing the otherwise lost Greek plays. ${ }^{9}$ However, because of the almost complete ${ }^{10}$ loss if not absence, or even invention, as has been suspected in some cases ${ }^{11}$ - of Plautus' models, a circular reasoning ${ }^{12}$ affects this speculative approach: given that Plautus' alleged 'models' are in fact a philological guess inferred from his

“Amphitruo was a daring experiment." Moore 1998, 110.

$5 \quad$ For etymology, mythology, genealogy (and aetiology as well) as discourses anchoring new notions in the recipients' common ground, see Sluiter 2015, 900-902. On the need to anchor an innovation to favour its acceptance, and more in general, on the concept of 'anchoring innovation', see Sluiter 2017, 20-38.

6 The issue of Plautus' relation with his Greek models, real or presumed, is "the Homeric Question of Latin Studies" (Halporn 1993, 191).

7 Feeney 2016, 45-64. Against this most recent perpetuation of the old paradigm cf. Wiseman 2016, 35sq.

8 See Asinaria 11: Demophilus scripsit, Maccus vortit barbare, and Trinummus 19: Philemo scripsit, Plautus vortit barbare.

9 For the state of the question and possible new approaches see Danese 2002, 133-153, and 2014, 35-51. Fraenkel's work on the Plautinisches (1922) marked a turning point in the re-evaluation of Plautus' originality: see Fraenkel 196o (a later Italian edition revised by Fraenkel himself). See also the works of the so-called 'Freiburg School'.

10 Only Menander's fragmentary $\Delta i \varsigma \xi \xi \xi \alpha \tau \alpha \tau \hat{\omega} \nu$ can be compared with part of Plautus' Bacchides. See Handley 1968.

11 Vogt-Spira makes a case for Plautus' invention of the Greek model mentioned in Asinaria 10-11. See Vogt-Spira 1991, 32-34.

As pointed out in Barbiero 2016, 651sq. 
'barbarian versions', assessing the poet's work on such a comparative basis proves to be a self-referential operation.

Conversely, an investigation that overcomes such an approach - which is itself aetiological! - and looks instead for other possible (i.e. rhetorical and discursive) reasons lying behind Plautus' self-claimed reliance on certain models has been seldom attempted. ${ }^{13}$ The prologue to the Amphitruo lends itself to the exploration of a fresh non-comparative (thus non-aetiological) approach to the vexed question of Plautus' 'models'. ${ }^{14}$ It is worth pointing out that both several - Plautinists and Plautus' intended audience deem the Greek models (whatever this concept means) a normative point of reference. Therefore, they both need an aetiological explanation (either philologically shaped or performed on the stage) in order to contextualise and accept any Plautine innovation.

3

Wonder and Exchange: Meta-Theatrical Negotiations with the Audience

Mercury opens the Amphitruo with a sixteen lines-long ${ }^{15}$ offer of exchange for the audience (Pl. Am. 1-4):

ut vos in vostris voltis mercimoniis

emundis vendundisque me laetum lucris

adficere atque adiuvare in rebus omnibus,

et $u t . . .16$

As you want me to grant you abundant profits

while you are buying and selling goods,

and to assist you in every situation,

and as you ...

These very first lines already give an idea of what the whole prologue (ll. 1-152) will be about, namely suspense, surprise, and mediation. Notwithstanding his

13 Focussing on the Bacchides, Barbiero 2016 is a fresh attempt to abandon the traditional 'comparative' approach to Plautus' reference to Greek models.

14 Therefore, my chapter is not a contribution to the vexed Quellenforschung of the Amphitruo, which is outlined in Oniga 2002, 199-225.

15 This is the "longest sentence in P[lautus]" (Christenson 2000, 134).

16 The Latin text is from Lindsay's OCT edition (except for l. 59), translations are my own. 
almost complete disguise as a human, ${ }^{17}$ Mercury starts his self-introduction by mentioning his own habit of granting to the spectators commercial profits (ll. 1-7) and good news (ll. 8-10), thus identifying himself as a mediator, and precisely, albeit implicitly, as the messenger god..$^{18}$ Having to cope straightaway with the clash between Mercury's human aspect and divine powers, the audience is engaged in a game of guesswork, and thus kept in suspense..$^{19}$ Such suspense is prolonged until line 19, where Mercury finally discloses his own name (nomen Mercuriost mihi), to which he probably alluded already in line 1 (mercimoniis $\sim$ Mercurius). This double onomastic reference frames Mercury's role as

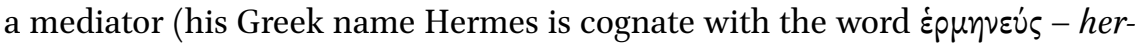
meneus - 'interpreter' ${ }^{20}$ ), thus stressing his prerogative, and anticipating its relevance also for his new mission as a prologist, during which he will accomplish several dealings with the audience, the first of which is the quid pro quo ${ }^{21}$ that opens the prologue and by which Mercury asks the spectators to reciprocate ${ }^{22}$ his favours by granting him their attention (1. 15) and fair judgment of the play $(1.16) .{ }^{23}$

Besides his own identity, Mercury discloses also that he is performing as a prologist on Jupiter's behalf (1. 19, Iovi' iussu venio). Later on, he addresses Jupiter both as 'the creator of benefits for everybody' (ll. 44-45, benefactis [...] architectust omnibus) and as 'the king of the gods' (1. 45, deorum regnator). More interestingly, Mercury adds that his father will 'personally take part in

17 The plot revolves around the machinations that Jupiter devises with the assistance of his son Mercury in order to seduce Alcumena, Amphitruo's wife. While Amphitruo and his slave Sosia are busy fighting a war, Jupiter takes on Amphitruo's guise staging his fake return to Alcumena, a device that allows him to sleep with her. Mercury disguises himself as Sosia in order to prevent the real Sosia, after he comes back, from interrupting his father's affair. During this intercourse Heracles is conceived, whose birth will mark the end of the play. The appropriation of the humans' identity by the gods triggers a series of misunderstandings, which characterises the Amphitruo as a 'comedy of errors'.

18 His divine status becomes clear at l. 12: mi esse ab dis aliis, nuntiis praesim et lucro.

19 The style (meter and alliterations), which makes the play begin as solemnly as a tragedy, also contributes to the audience's suspense. See more on Mercury's rapport with the audience in Moore 1998, 115sq.

20 See Feeney 1998, 27sq.

21 For Christenson 2000, 134 this is "an inverted prayer of the do ut des type".

22 At ll. 41-47 he denies this very intention, actually confirming it.

23 The god's desire to receive a positive response shines through even in the phrasing of his exchange, whose style is marked by the anaphora of several $u t$-clauses listing his benefits in the first fourteen lines (ll. 1, 4, 8, 9, 13, 14), which are counterbalanced by only two respective ita-clauses in the last couplet (ll. 15-16), where the object of his request is finally disclosed. Such a stylistic asymmetry not only suggests that Mercury's request is very generous compared to the spectators' considerable debt to him, but also shows once again his taste for suspense, given the delayed disclosure of his appeal. 
the comedy/play' (1. 88, ipse hanc acturust Iuppiter comoediam, and l. 94, hanc fabulam, inquam, hic Iuppiter hodie ipse aget). Although in this instance comoediam/fabulam agere primarily means that Jupiter will perform as an actor, if we instead understand the phrase's other possible meaning, namely 'to enact the comedy/play', ${ }^{24}$ Mercury's portrayal of his father then seems to imply that Jupiter's ordinary role as king of the gods and architectus will be mirrored on the stage through his assumption of a meta-theatrical position similar to that of a director of the play. Given that the plot is based on the intrigues devised by Jupiter to seduce Amphitruo's wife Alcumena, the development of the story turns out in fact to depend on his directions. ${ }^{25}$

But Mercury's most crucial revelation is the following (ll. $\left.5^{\mathrm{O}}-55\right)$ :

nunc quam rem oratum huc veni primum proloquar;

post argumentum huius eloquar tragoediae.

quid? contraxistis frontem quia tragoediam

dixi futuram hanc? deu' sum, commutavero.

eandem hanc, si voltis, faciam 〈iam〉 ex tragoedia

comoedia ut sit omnibus isdem vorsibus.

Now, I'll first tell you what I came here to ask, and then I'll outline the plot of this ... tragedy!

What? Did you frown because I said

that this would be a tragedy? I'm a god: I'll change it!

If you want, I'll turn this very tragedy into a

comedy without changing its verses.

Mercury envisages a sudden feeling of wonder - this emotion is like a refrain that resounds in the whole prologue ${ }^{26}$ - striking the audience with his unexpected utterance of the word 'tragedy'.27 The god's declared priority to disclose first the object of his request (which in fact has been already revealed

24 See $O L D$ s.v. ago 25 , and the following note.

25 See Slater 2000, 198; Moore 1998, 112. In a meta-theatrical aside, at l. 868, Jupiter confirms his intention to bring the play to an end himself: ne hanc incohatam transigam comoediam. Plautus himself might have interpreted Jupiter, continuing his previous experience as an author and performer of Atellanae: see Hanses 2014, 238, n. 46. On the possible meta-theatrical meaning of the word architectus see Christenson 2000, ad 45 and Schoeman 1998, 37. Conversely, for the hypothesis that Mercury interprets the role of the playwright (the alter-Plautus), see Sharrock 2009, 133sq.

26 See Christenson 2000, 29-31.

27 Also in the prologues of Captivi, Poenulus, and Rudens Plautus plays with the audience's generic expectations in a similar way. 
at ll. 15-16), and its immediate deferment because of the ensuing necessity to cope with the spectators' bewilderment, is pure fiction. ${ }^{28}$ The paraprosdokian effect triggered by the pronunciation of the word tragoediae at the end of an almost formulaic line where comoediae is expected instead (as in 1. 96: dum huius argumentum eloquar comoediae; cf. Miles gloriosus $11.84-85$ ) is a device that allows our god to simulate improvisation, ${ }^{29}$ and show the audience that by his divine powers he can immediately change the genre of the drama (note the rapidity expressed through the asyndeton: deus sum, commutavero) for the sake of their satisfaction.

In the light of the above meta-theatrical considerations, it could be thought that Mercury, as a prologist, would be subject to the director of the play (i.e. Jupiter) and limit himself to acting as his mouthpiece by merely fulfilling his orders. Instead, Mercury never gives any impression of passivity. What is more, Mercury gives the impression that the ultimate duty to fulfil the public's expectations urges him even to reshape what his father, the omnipotent 'architect', has entrusted to him. More importantly, he also gives the impression that the spectators, by showing their feelings, can influence the making of the play. This illusory meta-theatrical interaction between audience and prologist characterises the account of the impromptu transformation of the Amphitruo into a comedy as an 'interactive' aetiology, for the audience's disappointment is presented as the extemporaneous ail 1 iov that directly triggers the creation of the current comedy.

\section{Tragicomoedia: Literary Invention or Aetiological Pretext?}

At first glance, spectators are witnessing an unusual kind of vertere: instead of the familiar 'barbarian translation' from Greek to Latin mentioned in other Plautine prologues, Mercury announces the imminent translation of the play's genre. The Amphitruo features therefore a double metamorphosis, namely the gods' transfiguration into humans, and its own from tragedy to comedy. ${ }^{30}$ While the former transformation does not take place onstage, the latter is

\footnotetext{
28 See Hollmann 2016, 87-116 (especially 97-101, and 111).

29 Some improvisatory techniques in the Amphitruo prologue are listed in Auhagen 1999, 111-129.

30 Fusillo 1998, 73-81; Hanses 2014, 242-255. See Bettini 2012, 37-59 for the relationship between vertere and metamorphosis. Vertere is the word used at l. 121 to describe Jupiter's transformation into Amphitruo (in Amphitruonis vortit sese imaginem). See Hanses 2014 on the reception of the Amphitruo in Ovid's Metamorphoses (esp. 231-233).
} 
instead performed before the audience by Mercury himself, even though only by words. ${ }^{31}$

In fact, despite his initial promise, the play is not turned into a full comedy. Mercury points out that although he perfectly knows the audience's desiderata $(1.58),{ }^{32}$ he cannot comply with his own initial promise of giving them a comedy. As he reveals, there are some internal obstacles that impede a full transformation of the play's genre (1l. 59-63):
faciam ut commixta sit tragico comoedia..$^{33}$
nam me perpetuo facere ut sit comoedia, reges quo veniant et di, non par arbitror.
quid igitur? quoniam hic servos quoque partis habet, faciam sit, proinde ut dixi, tragico[co]moedia.

I'll make it be a comedy mixed with a bit of tragedy.

For I don't think it's fair to transform into a full comedy a play where kings and gods perform.

What then? Since the slave too has some parts,

I'll transform it into a tragicomedy, according to what I said.

The impossibility to fully satisfy the audience's expectations is explained as due to the impossibility to change the dramatis personae of the alleged original tragedy: hence the presence of gods and kings in the Amphitruo (1.61). Mercury further points out that gods and kings are not suitable characters for a comedy, and this binds him to the transformation of the play, at best, into a 'comedy mixed with some tragic flavour' (l. 59). After presenting the inescapable presence of kings and gods as the Amphitruo's tragic ailiıv, Mercury provides also the comic ail iov by explaining why the play can be identified in its essence as a comedy, or, as he calls it, as a 'tragicomedy'. The Amphitruo, he says, will feature also the servus (implicitly callidus), who is the comic character par excellence

31 I owe the term '(semi)performative' (and its application to the function of Mercury's meta-theatrical claims) to Gonçalves 2015, 54-69.

32 Teneo quid animi vostri super hac re siet.

33 With Traina 2000, 47, n. 59 and against current editors, I follow the reading of the manuscripts tragico comoedia, without expunging one syllable -co- as a dittography, and rejecting Leo's integration $\langle$ sit $\rangle$. Tragico can be interpreted as an instrumental ablative (of the substantivised neuter adjective tragicum, with an abstract meaning) depending on commixta. Only after explaining the aetiology of the tragicomedy at ll. 6o-62, Mercury actually creates the hapax 'tragicomoedia' at l. 63. Here there is most likely an actual extra syllable - $\mathrm{co}^{-}$, probably due to the copyist's excessive confidence in Mercury's remark proinde ut dixi, which made him transcribe tragico comoedia from l. 59 literally. 
for the intended Plautine spectator. After this brief explanation of the play's current status quo, the prologist concludes his mediation by presenting the new hybrid genre as a compromise he created (note the first person in faciam) in spite of his initial promise. ${ }^{34}$

In fact, Mercury's announcement of the birth of a new dramatic genre is not meant to be serious, for the Amphitruo is a comedy. The label tragicomoedia occurring in line 63 (see the above-given version of 1.59) is a hapax that in fact no later Roman author will ever adopt as a generic definition, since there will not be such a thing as a tragicomic genre..$^{35}$ Moreover, in the rest of the Amphitruo Plautus makes both Mercury and Jupiter call the play 'comedy' (as at 1.88 in the next passage), which suggests that he does not really regard the Amphitruo as a tragicomedy. ${ }^{36}$ In addition, according to the morphology and semantics of Latin compounds, the term tragicomoedia is still the definition of a comic genre. ${ }^{37}$ Therefore, the function of this passage is on the one hand to surprise the audience, and on the other hand to display Mercury's expertise at defining literary genres. ${ }^{38}$ The 'sociological' principle by which he categorises characters into tragic or comic ones goes back to the peripatetic tradition, finding echoes in Aristotle's Poetics. ${ }^{39}$ In the light of such an important reference, Mercury's announcement of a tragicomedy sounds even more daring, for the Amphitruo is presented as undermining the generic boundaries established by an authoritative literary tradition.

However, Mercury's literary criticism enables him at the same time to justify the novelty of the Amphitruo by showing that, when taken singularly, the traditional tragic and comic definitions still apply. By performing (note the double occurrence of the verb faciam) the play's generic metamorphosis in front of the spectators, our god actually splits the tragic and comic aspects of the drama showing their respective adherence to the traditional definitions. That said, Mercury's invention of the pretext of the public's rejection of an initial tragedy and of its 'live' transformation into a comedy dissimulates that Plautus

34 On the close relationship between mediation and translation in antiquity see Bettini 2012, 122-143.

35 "[T] he term tragicomedy was coined [by Plautus] as a joke" (Foster 2016, 16. See the whole chapter The Name of Tragicomedy. Problems of Identity for the history of the term 'tragicomedy' as a generic label from the Renaissance onwards, pp. 9-34).

36 See also ll. 96; 868; 986-987, and Dupont's introduction in Gonçalves 2015, xvii.

37 See Oniga 1988, 132sq, esp. n. 46.

38 Moore 1998, 113sq.

39 Arist. Po. 1448a. See Christenson 200o, ad 6o-63 and Hunter 2016, 18sq. Paradoxically, in the Amphitruo kings and gods actually accomplish a comic function, whereas human characters, Alcumena above all, manifest (also) tragic attitudes, for which see Gunderson 2015, 211-216. 
has thought well in advance about some recipients' possible concerns with the play's novelty, ${ }^{40}$ and therefore premeditated how to facilitate their acceptance of it. This pre-emptive defence is shaped as a little introductory show entrusted to the seeming improvisation of Mercury, who presents in an aetiological dialectic the relation of Plautus' work with the current literary conventions.

\section{$5 \quad$ 'Not (Completely) New': Finding an Origin for Originality}

There are two passages in the prologue to the Amphitruo where Mercury deals specifically with the innovative aspects of the comedy. A first chance to discuss what might, or as he puts it, might not be perceived as 'new' in the play is offered to Mercury right after announcing to the audience that Jupiter himself will perform in the play (ll. 88-93):
ipse hanc acturust Iuppiter comoediam.
quid? admiratin estis? quasi vero novom
nunc proferatur Ióvem facere histrioniam;
etiam, histriones anno quom in proscaenio hic
Iovem invocarunt, venit, auxilio is fuit.
praeterea certo prodit in tragoedia.

Jupiter himself will perform in this comedy.

What? Are you surprised? As if truly a novelty were offered now, namely that Jupiter performs as an actor.

Yet last year, when on this stage the actors

invoked Jupiter, he came to their aid.

Moreover, he definitely appears in tragedy.

Although this is not the first time that Mercury makes such an announcement inviting the spectators not to wonder at Jupiter's concerns as an actor, ${ }^{41}$ his histrionia (1. 88) is imagined to really surprise the public only now. Unlike previous cases, the remark quid? admiratin estis? suggests that this time Mercury envisages the audience actually feeling astonished. In fact, just as he did when announcing the play's tragic argumentum (see ll. $5^{2-53}$ above), here too the prologist aims to insinuate that bewilderment is the feeling with which he

40 On the audience's theatrical knowledge see Slater 2014, 110-113.

41 Cf. l. 29 on his 'human' fear of the audience's judgement, and ll. 86-87 - right before this passage - on his fear of claques. 
expects the spectators to receive this news. Mercury himself suggests the reason of this implied reaction, namely the novelty represented by Jupiter's performance. ${ }^{42}$ In order to dissimulate his effort to influence the spectators' emotions, he phrases his address in a negative way, inviting them not to (mis)take the god's histrionia 'as something new'. In fact, novelty is the very feature to which he wants to draw the audience's attention, therefore his denial proves to be highly affected and rhetorical.

The same applies to the defence that Mercury develops against the imaginary charge of introducing some novum in the dramaturgy of a comedy. His reminder that the previous year Jupiter appeared in a drama following some actors' call for his intervention, suggests that the king of the gods already manifested himself as a deus ex machina ${ }^{43}$ a typical tragic feature which implies that he recently performed in a tragedy. ${ }^{44}$ Consequently, Mercury ends this mini-apology by declaring Jupiter's participation suitable to tragedy (l. 93). ${ }^{45}$ In fact, such a defence of the god's participation in the Amphitruo, ${ }^{46}$ which just few lines earlier was defined as a comedy (1. 88), proves to be inconsistent, and aims rather to play once more with the spectators' generic expectations and literary knowledge.

A second possible novelty of the Amphitruo is discussed right after Mercury's summary of the first half of the plot (ll. 97-115), when the god comes to his own role in the story. At this stage of the prologue, he draws the audience's attention to his own disguise as follows (ll. 116-119):

nunc ne hunc ornatum vos meum admiremini, quod ego huc processi sic cum servili schema: veterem atque antiquam rem novam ad vos proferam, propterea ornatus in novom incessi modum.

Now, don't be surprised at this costume of mine, because I have come here disguised like this, as a slave:

42 Slater 2014, 117 observes that Jupiter's appearance on the stage was actually quite rare both in Greek and Roman drama.

43 Stewart 1958, 36osq.

44 At Rudens 86 (non ventus fuit, verum Alcumena Euripidi) Plautus proves to know a tragic version of this myth, possibly a Latin adaptation by Ennius. At ll. 41-44 Mercury lists some gods he saw appearing in other tragedies (ut alios in tragoediis/vidi ...).

45 Some editors expunge this as a gloss.

46 At the end of the play (scene 5.1), he does manifest as a deus ex machina. See Hanses 2014, 226. Conversely, Slater 2014, 122-124 seems to argue for the god's appearance on a roof, like in a theologeion. 
I'll bring you an old and ancient thing anew,

this is why I have come here dressed up in a new way.

Once again, Mercury abruptly invites the spectators not to be surprised at his slave costume, as if it started being an issue only at this point. Lines 124-128 explain it as part of Jupiter's plan to seduce Alcumena, which in the course of the play will compel Mercury to deceive Sosia by stealing his identity and thus keep him far from his father's liaison. However, the explanation comes somewhat late, for Mercury has been wearing this costume since the opening of the prologue without explaining why. This device enables Mercury not only to keep the audience, who are certain of little beyond his divine name, in suspense, but also to associate the issue of his disguised appearance with the issue of the insertion of gods into a comedy, and thus pick up on the discussion about novelty which started with the debate on Jupiter's histrionia.

Unlike before, here (1. 119) Mercury reveals straightforwardly that the newness of his disguise is the reason why the audience should wonder at it. He explains the alleged novelty of his 'entering the stage disguised in a new way' in a tautological manner, for he says that it springs from the renewal (the predicative function and position of novam - 'anew' - is crucial) of an 'old and ancient thing', namely of some previous dramatic treatment of the myth revolving around Heracles' birth..$^{47}$ Our lack of information about aspects such as slaves' costume ${ }^{48}$ and pre-Plautine dramas about Amphitruo ${ }^{49}$ prevents us from establishing in regard to what Mercury's 'way to wear the costume' is precisely new. However, in the light of what he has said so far, Mercury's claim seems to be more rhetorical than technical, being the natural conclusion of his explanation of the play's double nature. ${ }^{50}$

Even such a seemingly concrete gesture as pointing to the costume (l. 116, hunc ornatum, l. 117, sic cum servili schema) as visible evidence of the play's novelty is highly rhetorical. At line 143 the god reveals that, besides the slave's

47 Cf. Captivi 52: haec res agetur nobis, vobis fabula. For the prologist of the Captivi, the distinction between res and fabula is crucial: as an internal character, he regards the play as reality (res), whereas for the spectators it is pure dramatic fiction (fabula). For Christenson 2000, ad 118 res means 'play'.

48 Cf. Harpax's description of the slave Pseudolus' outward appearance in the eponymous play (ll. 1218-1220). On recurrent stories of slave disguise in Roman anecdotes, and on the social impact of clothing in ancient Rome (of slaves in particular), see George 2013, 41-45, and $49-51$.

49 See Stärk 1982, 275-303.

$5^{\circ} \quad$ "While all the implications of the statement are difficult to pin down, the close proximity of the words veterem and antiquam, as opposed to novam and novom, indicates some sort of antithesis or contrast between the traditional and the innovative" (Schoeman 1999, 44). 
disguise, he wears also some little wings - pinnulae - under his hat, which are Mercury's most peculiar identification mark as the messenger god. He therefore seeks to present himself as epitomising in his own costume the comic renewal of the mentioned 'very old' tragic repertoire, and as embodying his own promise to make the servus callidus appear in the play together with the $\operatorname{god}(\mathrm{s}) .{ }^{51}$ However, the concreteness of such a demonstration is mere illusion, for the spectators witness in fact an actor telling them that his way of wearing the slave costume is new because he formerly (i.e. in previous unspecified tragedies, or before his unseen/unperformed transformation into Sosia) used to dress up as a god! At the end of the prologue, the audience cannot but take this claim at face value, as well as the claim that the participation in a comedy of gods who actually look like human characters represents the most original feature of the Amphitruo.

\section{Conclusion: The Nature and Function of Plautus' Performed Aetiology}

The gods' participation in a comedy is not per se an absolute novelty. ${ }^{2}$ For the twofold sake of impressing the audience and promoting the Amphitruo as an original and worthwhile work, it seems that Plautus is willing to invent the newness of such a feature. By endowing Mercury with some literary expertise and thus making him his own mouthpiece, Plautus aims to present in the privileged space of the prologue his own art, discussing simultaneously its originality and its relationship with the established literary tradition. Even though by the time of the Amphitruo Plautus is a popular poet, he still feels the need to promote his comedies as new literary achievements, ${ }^{53}$ and while doing

51 See Dupont in Gonçalves 2015, xvii. In the play, Mercury will challenge and defeat in a servile one-upmanship (ll. 265-270) the real servus Sosia (who proves to be callidus at ll. 180-184, 198-200). At ll. 984-1004, Mercury shows himself aware of impersonating this role.

$5^{2}$ Gods do appear in Greek comedy (sometimes through the mechane, see Slater 2014, 107). Also the hybrid label 'tragicomedy' is not completely new, for the Sicilian comic poet Dinolochus already used the inverted term $x \omega \mu \omega \delta 0 \tau p \alpha \gamma \omega \delta i \alpha$ (test. 3 K.-A., PCG I 179).

53 Plautus develops this strategy more extensively (i.e. beyond the space of the prologue) also in the Bacchides, Casina and Pseudolus, which belong to the poet's maturity. Also the Asinaria, which is Plautus' oldest extant comedy, features the same promotion of the play as an innovative drama that is nevertheless anchored in an authoritative (i.e. Greek) literary tradition. For some more in-depth details on the chronology of Plautus' poetics of innovation see De March 2019, 16. In general, see De March 2019 for a detailed and 
this he seems to perpetuate a Greek comic topos that goes back to poets like Aristophanes and Antiphanes. ${ }^{54}$ By inventing the novelty of the mixed nature, tragic and comic, of his play (which is not a new device either ${ }^{55}$ ), Plautus brings this motif into the Amphitruo.

However, promoting oneself as an innovative playwright may give the impression, at least theoretically, that the accomplishment of literary innovations produces a radical break with the established tradition, which might compromise the acceptance of the 'new' as irregular and unorthodox. Therefore, it is "in order to make sure the audience responded warmly to his [Plautus'] plays" 56 that the prologue to the Amphitruo, besides presenting the drama as new, establishes also a relationship with literary tradition. Through a range of discursive characteristics such as polemics (i.e. the audience's fictitious objection), explanation, and causality, ${ }^{57}$ Mercury develops a discourse that tries to persuade the recipients that their concerns and fears of being disappointed are groundless.

The illusory device of the extemporaneous adaptation of a tragedy into a comedy that Mercury performs for the sake of the audience's satisfaction turns out to be a 'live aetiology', and, as such, an entertaining spectacle in itself. By virtue of this strategy, the play is traced back to an anonymous origin, a vetus atque antiqua res. The double stress on its antiquity conveys the idea that the source's alleged authoritativeness legitimises the metamorphosed version. Consequently, Mercury can finally conclude his performance by presenting the gods' presence in a comedy no longer as a daring innovation, but as something 'worthwhile' (operae pretium, l. 151) instead.

\section{Bibliography}

Auhagen, U. (1999). Elemente des Stegreifspiels im Amphitruo-Prolog. In: T. Baier, ed., Studien zu Plautus'Amphitruo. Tübingen: Gunter Narr, pp. 111-129.

Barbiero, E. (2016). 'Dissing' the $\Delta i \varsigma \xi \xi \xi \alpha \pi \alpha \tau \hat{\xi} \nu$. Comic One-Upmanship in Plautus' Bacchides. Mnemosyne, 69(4), pp. 648-667.

extensive analysis of all Plautus' statements on the novelty of his own plays. However, only in the Amphitruo the audience's acceptance is elicited by means of aetiology.

54 Plautus claims to be original several times in his plays (e.g. Captivi $53^{-} 58$, Casina 70 , and Pseudolus 568-569 above all). Aristophanes does the same in some of his parabases (see Bierl 2004, 9-19). Remarkable is Antiphanes' Poiesis (fr. 189 K.-A., PCG II 418sq.), on the comic poets' duty to innovate, unlike tragedians.

See n. 27 .

56 Moore 1998, 124sq.

57 Sluiter 2015, 902sq. 
Bettini, M. (2012). Vertere. Un'antropologia della traduzione nella cultura antica. Turin: Einaudi.

Bierl, A. (2004). Alt und Neu bei Aristophanes (unter besonderer Berücksichtigung der Wolken). In: A. von Müller and J. von Ungern-Sternberg, edd., Die Wahrnehmung des Neuen in Antike und Renaissance. Munich/Leipzig: K.G. Saur, pp. 1-24.

Christenson, D. (2000). Plautus. Amphitruo. Cambridge: Cambridge University Press.

Danese, R. (2002). Modelli letterari e modelli culturali del teatro plautino. Qualche problema di metodo. In: C. Questa and R. Raffaelli, edd., Due seminari plautini. La tradizione del testo. I modelli. Urbino: QuattroVenti, pp. 133-153.

Danese, R. (2014). Plauto, la commedia romana e i modelli greci. Revista de Estudios Latinos, 14, pp. 35-51.

De March, A. (2019). Lost in Barbarian Translation. The Anchoring Function of the Greek Models and the Poetics of Innovation in Plautine Comedy. Diss. Leiden.

Fantuzzi, M. (2006). Aetiology. Greek Literature. In: H. Cancik and H. Schneider, edd., Brill's New Pauly Online. Available at: http://dx.doi.org/10.1163/1574-9347_bnp_ el1119o [Accessed 3 November 2017].

Feeney, D. (1998). Literature and Religion at Rome. Cultures, Contexts, and Beliefs. Cambridge: Cambridge University Press.

Feeney, D. (2016). Beyond Greek. The Beginnings of Latin Literature. Cambridge, Mass.: Harvard University Press.

Foster, V. (2016). The Name and Nature of Tragicomedy. 2nd ed. London/New York: Routledge.

Fraenkel, E. (1960). Elementi plautini in Plauto. Florence: La Nuova Italia.

Fusillo, M. (1998). L'altro e lo stesso. Teoria e storia del doppio. Florence: La Nuova Italia.

George, M. (2013). Slave Disguise in Ancient Rome. In: T. Wiedemann and J. Gardner, edd., Representing the Body of the Slave, and ed. London/New York: Routledge, pp. 41-54.

Gonçalves, R. (2015). Performative Plautus. Sophistics, Metatheater and Translation. Newcastle upon Tyne: Cambridge Scholars Publishing.

Gunderson, E. (2015). Laughing Awry. Plautus and Tragicomedy. Oxford: Oxford University Press.

Halporn, J. (1993). Roman Comedy and Greek Models. In: R. Scodel, ed., Theater and Society in the Classical World. Ann Arbor: University of Michigan Press, pp. 191-213. Handley, E. (1968). Menander and Plautus. A Study in Comparison. London: H.K. Lewis. Hanses, M. (2014). Plautinisches im Ovid. The Amphitruo and the Metamorphoses. In: I. Perysinakis and E. Karakasis, edd., Plautine Trends. Studies in Plautine Comedy and its Reception. Berlin/Boston: De Gruyter, pp. 225-258.

Hollmann, E. (2016). Die plautinischen Prologe und ihre Funktion. Zur Konstruktion von Spannung und Komik in den Komödien des Plautus. Berlin/Boston: De Gruyter. 
Hunter, R. (2016). Some Dramatic Terminology. In: S. Frangoulidis, S. Harrison and G. Manuwald, edd., Roman Drama and its Contexts. Berlin/Boston: De Gruyter, pp. $13-24$.

Lindsay, W. (1904). T. Macci Plauti Comoediae, vol. 1. Oxford: Clarendon press.

Moore, T. (1998). The Theater of Plautus. Playing to the Audience. Austin: University of Texas Press.

Oniga, R. (1988). I composti nominali latini. Una morfologia generativa. Bologna: Pàtron.

Oniga, R. (2002). I modelli dell'Anfitrione di Plauto. In: C. Questa and R. Raffaelli, edd., Due seminari plautini. La tradizione del testo. I modelli. Urbino: QuattroVenti, pp. 199-225.

Schoeman, A. (1998). Mercury and Metatheatre. The antelogium in Plautus' Amphitruo. Akroterion, 43, pp. 32-42.

Schoeman, A. (1999). Mercury and Metatheatre II. The argumentum in Plautus' Amphitruo. Akroterion, 44, pp. 38-55.

Sharrock, A. (2009). Reading Roman Comedy. Poetics and Playfulness in Plautus and Terence. Cambridge: Cambridge University Press.

Slater, N. (2000). Plautus in Performance. The Theatre of the Mind. 2nd ed. Amsterdam: Harwood Academic Publishers.

Slater, N. (2014). Gods on High, Gods Down Low. Romanizing Epiphany. In: I. Perysinakis and E. Karakasis, edd., Plautine Trends. Studies in Plautine Comedy and its Reception. Berlin/Boston: De Gruyter, pp. $105^{-126 .}$

Sluiter, I. (2015). Ancient Etymology. A Tool for Thinking. In: F. Montanari, S. Matthaios and A. Rengakos, edd., Brill's Companion to Ancient Greek Scholarship, vol. 2: Between Theory and Practice. Leiden/Boston: Brill, pp. 896-922.

Sluiter, I. (2017). Anchoring Innovation. A Classical Research Agenda. European Review, 25(1), pp. 20-38.

Stärk, E. (1982). Die Geschichte des Amphitryonstoffes vor Plautus. Rheinisches Museum für Philologie, 125(3-4), pp. 275-303.

Stewart, Z. (1958). The Amphitruo of Plautus and Euripides' Bacchae. Transactions and Proceedings of the American Philological Association, 89, pp. 348-373.

Traina, A. (2000). Comoedia. Antologia della palliata. $5^{\text {th }}$ ed. Padua: CEDAM.

Vogt-Spira G. (1991). Asinaria oder Maccus vortit Attice. In: E. Lefèvre, E. Stärk and G. Vogt-Spira, edd., Plautus barbarus. Sechs Kapitel zur Originalität des Plautus. Tübingen: Gunter Narr, pp. 11-69.

Wiseman, T. (2016). Was It Really a Translation? Review of Beyond Greek. The Beginnings of Latin Literature by D. Feeney. London Review of Books, 38(18), pp. 35-36. 